\title{
Ethanol Extract of Choerospondias axillaris Fruit Pulp Enhances Haematological Parameters in Oncorhynchus mykiss Cultured in Nepal
}

\author{
Shubha Ratna Shakya ${ }^{12 *}$ and Shyam Narayan Labh ${ }^{2}$ \\ 1Central Department of Zoology, Tribhuvan University \\ ${ }^{2}$ Amrit Campus, Tribhuvan University, Nepal
}

\begin{abstract}
The present outdoor experiment was carried out to evaluate the effect of dietary supplementation of lapsi Choerospondias axillaris (Roxburgh, 1832) on haematological parameters in rainbow trout Oncorhynchus mykiss in Nepal. The lapsi fruits were obtained from local market of Kathmandu. The feeding trail was conducted for 90 days. About 270 trout with similar body weight $(5 \pm 1 g)$ were distributed randomly at the rate of 15 fishes per cage $\left(1 \mathrm{~m}^{3}\right)$ into 18 cages placed in raceway pond. Six practical diets containing $40 \%$ protein were prepared as T1 $\left(0.0 \mathrm{~g} \mathrm{~kg}^{-1}\right) \mathrm{T} 2\left(0.1 \mathrm{~g} \mathrm{~kg}^{-1}\right)$, T3 (0.2 g kg-1), T4 (0.4 g kg-1), T5 (0.8 $\left.\mathrm{g} \mathrm{kg}^{-1}\right)$ and T6 (1.6 $\left.\mathrm{g} \mathrm{kg}^{-1}\right)$ supplemented by the ethanol extract of lapsi fruits along with other usual ingredients viz. fish meal, wheat flour and cod liver oil etc. At the end of the experiment the haematological parameters were measured. A significant difference $(P<0.05)$ in haematological parameters was observed between the treated diets fed groups to that of control diet fed group. Total erythrocytes count (RBC), Haematocrit (Hct), Haemoglobin concentration $(\mathrm{Hb})$, and erythrocyte indexes (MCV, $\mathrm{MCH}$ and $\mathrm{MCHC}$ ) were found significantly higher in T4 (0.4\%) diet fed trout as compared to the control. A minimum of $0.4 \%$ $(0.4 \mathrm{~g} \mathrm{~kg}-1)$ lapsi fruit extract in fish feeds gave more increase in haematological parameters of Oncorhynchus mykiss. Inclusion of lapsi fruit extract at $0.4 \%$ concentration is therefore could be used effectively in aquaculture.
\end{abstract}

Keywords: Oncorhynchus mykiss, growth, lapsi, haematocrit, haemoglobin

*Corresponding author

Email: shubharatnashakya@gmail.com

\section{Introduction}

Aquaculture is one of the important sectors contributing significantly in the Nepalese economy. Aqua farmers are encouraged towards intensification of culture system to increase production and profit in the world [1]. In intensive aquaculture stress level in fish impairing immune responses against pathogens leads to disease outbreaks in fishes [2, 3]. Disease is one of the most important constraints of fish production both in culture system, as well as wild condition. Fish production is decreased due to the occurrence of disease caused by different pathogens in aquaculture. To overcome this problem and to achieve the sustainable development of aquaculture, control of infectious diseases, parasites and maintenance of good health of cultured fish concern the most.

Various chemical agents, herbal extracts, and nutritional factors which stimulate the nonspecific defence mechanisms are used for growth performance and control of infectious diseases in fish [4] caused by various pathogens. Despite the use of a large number of antibiotics, drugs, pesticides, and chemotherapeutics to control diseases, they are not so effective and ecologically unsafe.

Several studies have confirmed the presence of active ingredients responsible for various biological activities [5] in plants and many of them have already been tested against various diseases to test its immunostimulant efficacy [6] in aquaculture. There are several medicinal plants used in fish aquaculture are Cassia alata, Calophyllum inophyllum, Clinacanthus nutans, Clinacanthus sp., Glinus oppositifolius, Hura crepitan, Momordica charantia, Ocimum sanctum (red), Ocimum sanctum (white), Ochrocarpus siamensis, Phyllanthus acidus, Phyllanthus amarus, Phyllanthus debelis, Phyllanthus reticulatus, Phyllanthus urinaria, Psidium guajava, Tinospora crispa, Tinaspora cordifolia [7]. Additionaly, many herbal extracts have been tested or its efficacy 
against bacterial challenge in fish [8]. Dietary supplementation of Anthra quinone extract, Zingiber officinale and Curcuma longa stimulated immunity and enhanced resistance against pathogen aggravated stress in fish. Similarly, feed incorporated with natural herb enhanced the non specific immune responses in C. mrigala against the pathogen aggravated stress of Pseudomonas aeruginosa $[9,10]$.

Nowadays, the use of natural plants as growth promoter and immune-stimulator along with their compounds such as essential oils and herbal extracts has improved the non-specific immune system in fishes. Use of medicinal plants is a suitable alternative to synthetic antibiotics, chemical growth agents and synthetic immune-stimulants. Herbal drugs improve the immune system and increase the host's resistance to disease by increasing the number of white blood cells and production of antibodies [11]. Citarasu et al., (2006) reported that immune-stimulants are substances, which increase the non-specific defense mechanism and provide resistance against pathogenic organisms [12]. Thus the use of cheaper and effective natural herbal extracts in the diet of fishes is gaining momentum which is less toxic and reduces the residual load to the aquatic environment [13]. These herbal extracts in aqua feed are less toxic and reduce residual load in the aquatic environment.

Dietary natural herbs incorporation not only enhance growth but also lead to an augmentation in non-specific immunity, antioxidation, enzyme activity, and disease resistance in fish due to presence of active phytochemicals $[14,8,15]$.

Improving immune system in valuable fish species such as rainbow trout is the most important in cold water aquaculture. Food additives, growth stimulants and immunestimulants, including chemical agents, nutritional factors, bacterial and probiotic components, and animal or plant extracts affect the immune system and body defenses against disease agents [16]. Increased use of antibiotics, growth stimulants and chemical compounds leads to increased resistance of microorganisms against antibiotics and drugs. Antibiotic resistance is one of the most fundamental problems in aquaculture industry [17]. Drug resistance, decreased meat quality and high cost lead to the use of natural stimulants in fish farming, especially herbal and traditional plants [18].

Nowadays, the use of natural plants as growth and immune stimulant factors along with their compounds such as essential oils and herbal extracts has improved the non-specific immune system in fish farming. Using traditional and medicinal plants as safety stimulants is a suitable alternative to synthetic antibiotics, chemical growth agents and immune stimulants. Immune stimulants, especially herbal medicine improve the immune system and increase the host's resistance to disease via increasing the number of white blood cells and production of antibodies [11].

Lapsi, Choerospondias axillaris (Roxburg, 1832) of family Anacardiaceae is grown in 301 Village Development Committees of 29 hill districts of Nepal [19]. Its fruit is rich in vitamin C content [20] and enhance the immune system [21] of the organisms. Phenolic and flavonoid compounds [22] present in lapsi fruit pulp are antioxidant agents which can inhibit free radicals, so they can be effective in preventing many oxidative diseases such as cancer. These compounds also have antibacterial and antifungal effects [23].

Rainbow trout Oncorhynchus mykiss (Walbaum, 1792),) is the most preferred cold water fish species in aquaculture industry of Nepal It is one of the commercially cultured cold water fish in Nepal. It is an exotic fish species introduced in 1968 and 1971 from India and in 1988 from Japan to substitute fish import in star hotels catering for tourists, use of cold-water resources for aquaculture and to promote of fishing tourism in hill and mountains of Nepal for uplifting the living standard of people [24]. It is an important commercial fish in Nepal with maximum market demand and acceptability as food by the consumers due to their taste and flesh. The "One Village One Product (OVOP)" program has selected rainbow trout as one of the products in Nepal from 2063/64. This program 
was implemented in Nuwakot District in the same FY 2063/64 in order to promote and product cold water fish farming.

Haematological parameters are gradually becoming a routine practice for monitoring health status in fish $[25,26,27]$ to interpret physiological responses to environmental stress $[28,29]$ and changes in the proportion of blood cells may be indicative of a disease or an exposure to chemicals [30]. Blood indices must be analyzed when animals are exposed to pollutants [31], stress [32], infections [33, 34], parasitism [35] and seasonality [30]. Blood parameters changes during diseases or any changes occurring in the organism as a result of injuries to organs or tissues related to infectious diseases [36, 37].

It has been observed that blood parameters such as haematocrit, haemoglobin concentration and RBC count are related to environmental factors such as water temperature and salinity [38]. The knowledge of the haematological parameters can be used as an effective and sensitive index to monitor physiological and pathological changes in fishes [39]. Normal ranges for various blood parameters in fish have been established by different researchers in fish physiology and pathology [40,41].These parameters are also closely related to the response of the fish to the environment, an indication that the environment where fish lives could exert some influence on the blood characteristics [42, 43]. Haematological parameters of Rainbow trout fingerlings fed with lapsi fruit extract supplemented diet have not studied. Thus, the present study was conducted to evaluate the efficacy of lapsi extract in different amount in diets on some haematological parameters of Rainbow trout in intensive aquaculture.

Table 1. Ingredients of experimental diets (\%)

\begin{tabular}{|c|c|c|c|c|c|c|}
\hline \multirow{2}{*}{ Ingredients } & \multicolumn{6}{|c|}{ Experimental Diets (\% inclusion) $\mathrm{g} \mathrm{kg}^{-1}$} \\
\hline & $\mathrm{T} 1$ & $\mathrm{~T} 2$ & T3 & $\mathrm{T} 4$ & T5 & T6 \\
\hline Fish Meal ${ }^{\dagger}$ & 29.31 & 29.31 & 29.31 & 29.31 & 29.31 & 29.31 \\
\hline Soya meal ${ }^{\ddagger}$ & 14.52 & 14.52 & 14.52 & 14.52 & 14.52 & 14.52 \\
\hline Groundnut oil cake $^{\dagger}$ & 9.17 & 9.17 & 9.17 & 9.17 & 9.17 & 9.17 \\
\hline Rice Powder ${ }^{\dagger}$ & 14.16 & 14.16 & 14.16 & 14.16 & 14.16 & 14.16 \\
\hline Wheat Flour ${ }^{\dagger}$ & 14.43 & 14.43 & 14.43 & 14.43 & 14.43 & 14.43 \\
\hline Corn flour ${ }^{\dagger}$ & 11.37 & 11.37 & 11.37 & 11.37 & 11.37 & 11.37 \\
\hline Sunflower oil ${ }^{\dagger}$ & 3 & 3 & 3 & 3 & 3 & 3 \\
\hline Cod liver oil ${ }^{\dagger}$ & 2 & 2 & 2 & 2 & 2 & 2 \\
\hline Vitamin \& Mineral Premix $\$$ & 1 & 1 & 1 & 1 & 1 & 1 \\
\hline C. axillaris extract ${ }^{\dagger}$ & 0 & 0.01 & 0.02 & 0.04 & 0.08 & 0.16 \\
\hline Betain Hydrochloride†† & 0.02 & 0.02 & 0.02 & 0.02 & 0.02 & 0.02 \\
\hline BHT(Butylated hydroxytoluene)†† & 0.02 & 0.02 & 0.02 & 0.02 & 0.02 & 0.02 \\
\hline CMC (Carboxymethyl cellulose) †† & 1 & 0.99 & 0.98 & 0.96 & 0.92 & 0.84 \\
\hline Total & 100 & 100 & 100 & 100 & 100 & 100 \\
\hline
\end{tabular}

tIngredients like fish meal, soya meal, groundnut oil cake, rice powder, wheat flour, corn flour, sunflower oil and Cod Liver Oil were procured from local market of Kathmandu Valley.

贶uchi Soya Industries, Raigad, India.

\$Composition of vitamin mineral mix (EMIX PLUS) (quantity $2.5 \mathrm{~kg}^{-1}$ )

Vitamin A 55,00,000 IU; Vitamin D $311,00,000$ IU; Vitamin B 2, 2,000 mg; Vitamin E 750 mg; Vitamin K 1,000 mg; Vitamin $B_{6} 1,000$ mg; Vitamin $B_{12} 6 \mu$ g; Calcium Pantothenate 2,500 mg; Nicotinamide 10 g; Choline Chloride 150 g; Mn 27,000 mg; I 1,000 mg; Fe 7,500 mg; Zn 5,000 mg; Cu 2,000 mg; Co 450 mg; Ca 500 g; P 300g; L- lysine $10 \mathrm{~g}$; DL-Methionine $10 \mathrm{~g}$; Selenium $50 \mathrm{mgl}^{-1}$; Selenium $50 \mathrm{mgl}^{-1}$; Satwari $250 \mathrm{mgl}^{-1}$; (Lactobacillus 120 million units and Yeast Culture 3000 crore units).

†Fruits of $C$. axillaris were obtained locally and then extracts were prepared from the pulp of lapsi fruits. ††Himedia Laboratories, Mumbai, India. 
Table 2. Proximate composition of experimental diets (\%)

\begin{tabular}{lcccccc}
\hline \multirow{2}{*}{ Ingredients } & \multicolumn{7}{c}{ Experimental Diets } \\
\cline { 2 - 7 } & T1 & T2 & T3 & T4 & T5 & T6 \\
\hline Dry Matter $(\mathrm{DM})$ & 97.15 & 97.43 & 97.59 & 97.71 & 96.93 & 97.014 \\
Moisture & 2.85 & 2.57 & 2.41 & 2.29 & 3.07 & 2.986 \\
Crude Protein $(\mathrm{CP})$ & 31.16 & 31.07 & 31.32 & 31.14 & 31.22 & 31.239 \\
Ether Extract $(\mathrm{EE})$ & 6.56 & 6.37 & 6.11 & 6.98 & 6.755 & 6.855 \\
Crude Fiber & 8.32 & 8.32 & 8.43 & 8.79 & 8.845 & 8.997 \\
Ash & 9.23 & 8.73 & 9.53 & 7.69 & 7.84 & 7.458 \\
NFE & 44.73 & 45.51 & 44.61 & 45.4 & 45.34 & 45.451 \\
\hline
\end{tabular}

The use of lapsi in diet in aquaculture is thus anticipated to be an excellent strategy for the prevention of infectious microbial diseases and to replace antibiotics and chemotherapeutic.

\section{Materials and Methods Study area and period}

The experiment was carried out in Soodo Rainbow trout culture farm (Nepal) for 90 days. Rainbow trout were obtained from hatchery of Soodo Rainbow trout farm, private fish farm in Ranipauwa, Nuwakot district in Nepal.

\section{Experimental design}

The trout were acclimated for seven days feeding on control diet. A total of two hundred seventy acclimated trout of similar size (average weight $92.37 \pm 0.039 \mathrm{~g}$ ) were randomly allocated to 18 wooden bordered plastic cages placed in race way pond, 15 fish in each cage. There were three replicates for each treatment. T2, T3, T4, $\mathrm{T} 5$, and $\mathrm{T} 6$ were treatment groups and $\mathrm{T} 1$ was control. Temperature ranged from $12{ }^{\circ} \mathrm{C}$ to 19 ${ }^{\circ} \mathrm{C}$, dissolved oxygen ranged from 4.13 to 6.12 . $\mathrm{mg}^{-1}$ and $\mathrm{pH}$ ranged from 7.33 to 7.67 throughout the study period.

\section{Feed formulation and preparation of experimental diets}

The crude extract of the pulp of lapsi fruits was prepared by using ethanol (70\%) as described by [43]. Six experimental diets ( $40 \%$ protein) were prepared containing similar ingredient composition. Diet one was control diet (T1) without extract of lapsi fruits. Other five diets were supplements with lapsi fruit's extract $\mathrm{T} 2$ $\left(0.1 \mathrm{~g} \mathrm{~kg}^{-1}\right), \mathrm{T} 3\left(0.2 \mathrm{~g} \mathrm{~kg}^{-1}\right), \mathrm{T} 4\left(0.4 \mathrm{~g} \mathrm{~kg}^{-1}\right), \mathrm{T} 5(0.8 \mathrm{~g}$ $\left.\mathrm{kg}^{-1}\right)$ and $\mathrm{T} 6\left(1.6 \mathrm{~g} \mathrm{~kg}^{-1}\right)$. Table 1 shows the ingredients of the feeds.

\section{Proximate analysis of feeds}

The proximate composition of the experimental diets (Table 1) was analysed following the standard methods of the Association of Official Analytical Chemists [44]. The moisture content was determined by drying at $105{ }^{\circ} \mathrm{C}$ to a constant weight. Nitrogen content was estimated by automated Kjeldahl apparatus (2200 Kjeltec Auto distillation, Foss Tecator, Sweden) and crude protein was estimated by multiplying nitrogen percentage by 6.25 . Ether extract (EE) was measured using a Soxtec system (1045 Soxtec extraction unit, Tecator, Sweden) using diethyl ether (boiling point, 40$\left.60{ }^{\circ} \mathrm{C}\right)$ as a solvent and ash content was determined by incinerating the samples in a muffle furnace at $600{ }^{\circ} \mathrm{C}$ for 6 hours. Nitrogen free extract (NFE) was calculated by difference i.e., $\mathrm{NFE}=100-(\mathrm{CP}+\mathrm{EE}+\mathrm{CF}+\mathrm{Ash})$.

Nitrogen Free Extract $(\mathrm{NFE})=100-$ $(\mathrm{CP}+\mathrm{EE}+\mathrm{CF}+\mathrm{Ash})$

\section{Maintenance and feeding}

Each cage was covered by mosquito net to prevent the fish from jumping out. All cages were kept in the same raceway pond under adjust the feeding status of trout. The fish were hand fed at $3 \%$ of body weight two times a day at A randomly 5 trout were weighed from each cage biweekly interval to balance the diet.

\section{Blood Collection}

Three fish were randomly sampled from each cage and were anaesthetized with buffered tricaine methane suffocate (MS-222; $5 \mathrm{mg} \mathrm{l}^{-1}$ ). Blood was drawn from the caudal vein of treated and control fish using $2 \mathrm{ml}$ heparinized plastic syringes and gauge hypodermic needles. The syringe is flushed with ethylenediamine tetraacetic acid (EDTA) as the anticoagulant. 
Table 3. Haematological parameters of rainbow trout (Oncorhynchus mykiss) fed with diets of different levels (mean \pm SD) of lapsi fruit' pulp extract for 90 days of the experiment

\begin{tabular}{lcccccc}
\hline & \multicolumn{7}{c}{ Haematological Parameters } \\
\cline { 2 - 7 } Treatments & $\begin{array}{c}\mathrm{RBC} \\
\left(\times 10^{6} \mathrm{~mm}^{-3}\right)\end{array}$ & $\mathrm{Hb}(\mathrm{g} / \mathrm{dl})$ & Hct $(\%)$ & $\mathrm{MCV}(\mathrm{fl})$ & $\mathrm{MCH}(\mathrm{pg})$ & $\begin{array}{c}\mathrm{MCHC} \\
(\mathrm{g} / \mathrm{dl})\end{array}$ \\
\hline T1 & $4.15 \pm 0.396$ & $9.52 \pm 1.313$ & $30.57 \pm 1.06$ & $184.57 \pm 11.29$ & $38.50 \pm 11.85$ & $21.27 \pm 6.62$ \\
$\mathrm{~T} 2$ & $4.59 \pm 1.523$ & $12.07 \pm 3.444$ & $31.73 \pm 7.62$ & $177.87 \pm 4.00$ & $36.23 \pm 2.15$ & $22.05 \pm 6.34$ \\
$\mathrm{~T} 3$ & $4.61 \pm 0.912$ & $13.94 \pm 2.327$ & $32.65 \pm 0.53$ & $142.16 \pm 8.03$ & $35.56 \pm 7.25$ & $24.94 \pm 22.83$ \\
$\mathrm{~T} 4$ & $5.86 \pm 0.737$ & $15.24 \pm 3.204$ & $36.83 \pm 12.42$ & $130.94 \pm 4.00$ & $30.77 \pm 5.84$ & $29.99 \pm 0.07$ \\
T5 & $5.81 \pm 0.36$ & $14.57 \pm 2.082$ & $35.58 \pm 9.94$ & $157.58 \pm 13.65$ & $32.96 \pm 3.46$ & $28.49 \pm 6.80$ \\
T6 & $4.88 \pm 0.66$ & $14.22 \pm 1.151$ & $33.75 \pm 9.23$ & $165.51 \pm 26.03$ & $34.97 \pm 6.17$ & $25.41 \pm 9.54$ \\
\hline The collected blood was transferred & to &
\end{tabular}

The collected blood was transferred to eppendorfs of $1.5 \mathrm{ml}$ capacity and stored in refrigerator for further analysis. These blood samples were used for determining erythrocyte count [45] and hemoglobin concentration [46]. Heamatocrit values (Hct) were calculated according to the formulae mentioned by Britton [47).

\section{Haematological examination}

Total Red blood cells were determined in a 1:100 dilution of blood sample in Shaw solution [48] with an improved Neubauer haemocytometer according to the procedure described by [49].The total numbers were reported as $10^{6}$ per $\mathrm{mm}^{3}$ for RBC and $10^{3}$ per $\mathrm{mm}^{3}$ for WBC [50]. Haemoglobin concentration was estimated by standard cyanmethemoglobin method [51]. Heamatocrit value (Hct) was determined after blood centrifugation in micro-haematocrit capillary tube, using a micro-haematocrit centrifuge and micro-haematocrit reader [52]. The mean cell volume (MCV), mean cell haemoglobin $(\mathrm{MCH})$, and mean cell haemoglobin concentration (MCHC) were calculated [45] using the formulae:

$\operatorname{MCV}(\mathrm{fl})=($ Hct $/ \mathrm{RBC}) \times 10$

$\mathrm{MCH}(\mathrm{pg})=(\mathrm{Hb} / \mathrm{RBC}) \times 10$

$\operatorname{MCHC}(\mathrm{g} / \mathrm{dl})=(\mathrm{Hb} / \mathrm{Hct}) \times 100$

\section{Statistical analysis}

The results are presented as means $\pm \mathrm{SE}$, difference between haematological parameters among control and treatment groups were analyzed by one way analysis of variance (ANOVA) followed by Duncan's Multiple Range Test.

\section{Results}

The haematological parameter of rainbow trout (Oncorhynchus mykiss) fed with different doses of lapsi fruit extract was shown in Table 4. The Red blood cells count was significantly higher in treated groups compared to the control group (T1). Overall, a higher RBC count was found in the group fed with $\mathrm{T} 4$ diet $(5.86 \pm 0.737)$ compared with group fed with $\mathrm{T} 1$ diet (4.15 \pm 0.396$)$. Haemoglobin increased significantly in trout fed with treated diets compared with control $(\mathrm{P}<0.05)$. The maximum concentration of haemoglobin was recorded in the group fed with $\mathrm{T} 4$ diet (15.24 \pm 3.204$)$ followed by T5, T6, T3, T2 and the T1 (Table 3).

Haemocrit (Hct) was increased significantly in treated groups compared with control $(\mathrm{P}<0.05)$. The maximum Hct value was recorded in $\mathrm{T} 4$ $(36.83 \pm 12.42)$ group and minimum in control group (30.57 \pm 1.06$)$. The minimum $\mathrm{MCV}$ value was observed in T4 group (130.94 \pm 4.00$)$ and maximum values was recorded in control group $(184.57 \pm 11.29)$ and $\mathrm{MCH}$ maximum value was recorded in control group (38.50 \pm 11.85$)$ and minimum in T4 (30.77 \pm 5.84$)$. MCHC increased significantly in treated groups compared with control $(\mathrm{P}<0.05)$. MCHC maximum value was recorded in T4 (29.99 \pm 0.07$)$ and minimum in control group (21.27 \pm 6.62$)$.

RBC- Red blood cell count, Hb- Haemoglobin, Hct- haematocrit value, MCV- mean corpuscular volume, $\mathrm{MCH}-m e a n$ corpuscular haemoglobin, MCHC-mean corpuscular haemoglobin concentration.

$\mathrm{T} 1=$ Control (Without lapsi extract), T2=100 mg Lapsi extract $/ \mathrm{kg}$, T3= $200 \mathrm{mg}$ Lapsi extract $/ \mathrm{kg}$, 
$\mathrm{T} 4=400 \mathrm{mg}$ Lapsi extract $/ \mathrm{kg}$, T5 = $400 \mathrm{mg}$ Lapsi extract $/ \mathrm{kg}$ and T6 $=1600 \mathrm{mg}$ Lapsi extract $/ \mathrm{kg}$.

\section{Discussion}

In fishes, blood is a patho-physiological reflector of the entire body and the haematological parameters such as leucocyte count, erythrocyte count, hematocrit and hemoglobin are routinely tested to monitor the health status of fish and any deviation from the normal ranges may indicate a disturbance in the physiological process. [53,54]. The changes in the blood parameters of $C$. gariepinus caused by stress due to exposure to environmental pollutant, diseases or by pathogens have been studied by many researchers especially in capture fisheries $[55,56]$.

Hematological parameters may provide an index of the physiology status of fish which are directly influenced by sex, size, seasons, slow or fast movement and age of fishes [57] and indirectly influenced by quality of water, temperature, food availability physiological status of fish [58], microbial infection of fish and toxicants [59]. Ologhobo (1992) [60] reported that the most common blood variables consistently influenced by diet are the haematocrit (Hct) and haemoglobin ( $\mathrm{Hb}$ ) levels. The changes in $\mathrm{RBC}$ count, $\mathrm{Hb}$ concentration, Hct, MCV, MCH and MCHC show health status of fish [61]. Haemoglobin, RBC, Hct, MCV, $\mathrm{MCH}$ and $\mathrm{MCHC}$ values obtained in the experiment almost agreed with earlier workers. According to the results, lapsi extract supplemented diets could increase Hemoglobin content and RBC numbers in treated groups compared to control group. This agreed with the work of [62] who also reported similar increase in haematological parameters in Nile tilapia.

In agreement with the present findings, Sahu et al., (2007) [63] found higher RBC counts in Labeo rohita fingerlings fed with Magnifera indica kernel when compared to control. Shalaby et al., (2006) [64] reported significant increases in RBC, $\mathrm{Hb}$ and Htc of Nile tilapia fed with garlic that support the present study. Faisal (2003) [65] reported significant decrease of $\mathrm{MCH}$ and $\mathrm{MCV}$ in Clarias garepins fed with garlic that is also similar to the findings of the present study. $C$. gariepinus fed A. barbadensis leaves paste showed significant $(p<0.05)$ increase in haematocrit (Hct), haemoglobin, RBC, WBC in comparison to the control group. This was in agreement with the work of Haghigi and Rohani (2013) [66] who observed similar increase in the haematological parameters in rainbow trout fed ginger powder. These were also similar findings of Farahi et al. (2012) [67] who reported significant enhancement (higher values) of WBC and PCV in diet supplemented with $M$. officinalis and Aloe vera.

Concerning the effect of the lapsi supplemented diet on haematological parameters of rainbow trout (Oncorhynchus mykiss) indicated increased haematocrit, haemo-globbin, erythrocyte, $\mathrm{MCH}$, and $\mathrm{MCHC}$ in comparison to the control group $(\mathrm{p}<0.05)$ (Table. 3). These could be attributed to the fact that, the lapsi in the diet has increased the haematological parameter values as a result of hematopoietic stimulation $[68,69,70]$.

\section{Conclusion}

Number of chemicals and drugs used in aquaculture cause severe environmental problems. Most of the antibiotics and drugs are banned because of their negative impact and effluent remittance in the fish muscle which may cause side effect to the consumer. Herbal drugs, safer to fish and the environment are the viable alternative to antibiotics and other banned drugs. Most of the herbs and herbal extracts are given orally. The farmer does not know about the importance of herbal drugs. So it is necessary make aware on the use of biological and ecofriendly approach of herbs and their products in aquaculture to the farmers. It will reduce the production risk, negative impact and production cost and also increasing fish production with sustainable way. In conclusion, the present study revealed that lapsi, Choerospondias axillaris incorporated diet fed to rainbow trout, Oncorhynchus mykiss improved haematological parameters. Hence, $0.4 \mathrm{mg} \mathrm{kg}^{-1}$ lapsi extract could be used as a supplement in the diet of fish for better health. However, more research should be carried out on the uses of 
Choerospondias axillaris in order to obtain optimal health.

\section{Acknowledgment}

I would like thankful to former Head Dr. Ranjana Gupta for providing necessary facilities. Help rendered by Sonam Lama (owner of Soodo Rainbow trout farm), Bandana K.C., Mandira Poudyal and Chemmi Lama during the field surveys and fish sample collection are also gratefully acknowledged.

\section{References}

1. Mohapatra S, Chakraborty T, Kumar V, DeBoeck G, Mohanta KN: Aquaculture and stress management: a review of probiotic intervention. J Anim Physiol Anim Nutr. 2013 97: 405-430

2. Inendino KR, Emily GC, Philipp DP, Goldberg TL: Effects of Factors Related to Water Quality and Population Density on the Sensitivity of Juvenile Largemouth Bass to Mortality Induced by Viral Infection. J Aqu Anim Health. 2005 17: 304-314.

3. Small BC, Bilodeau AL: Effects of cortisol and stress on channel catfish (Ictalurus punctatus) pathogen susceptibility and lysozyme activity following exposure to, Edwardsiella ictaluri. Gen Comp Endocrinol. 2005 142: 256- 262

4. Raa J: The use of immunostimulatory substances of fish and shellfish farming. Rev fish Sci. 1996 4: 229-288.

5. Asimi OA, Sahu NP: Herbs/spices as feed additive in aquaculture. Scientific J Pure Applied Sci. 2013 2(8):284-292.

6. Ghosh U, Chakraborty S: Pharmaceutical and phytochemical evaluation of a novel anti white spot syndrome virus drug derived from terrestrial plants. Int J Nat Prod Res. 2013 3(4):92-101

7. Direkbusarakom S: Application of medicinal herbs to aquaculture in Asia. Walailak $J \mathrm{Sci}$ Tech. 2004 1(1):7-14

8. Yeh RY, Shiu YL, Shei SC, Cheng SC, Huang SY, Lin JC, Liu CH: Evaluation of the antibacterial activity of leaf and twig extracts of stout camphor tree, Cinnamomum kanehirae, and the effects on immunity and disease resistance of white shrimp, Litopenaeu vannamei. Fish Shellfish Immun. 2009 27: 26-329

9. Sivagurunathan A, Amila MK. Innocent BX: Investigation of immune-stimulant potential of Zingiber officinale \& Curcuma longa in Cirrhinus mrigala exposed to Pseudomonas aeruginasa Haematological assessment. Int $J$ Res Ayurveda Pharm. 2011 2(3): 899-904.
10. Kumar S, Prakash C, Gupta SK, Chadha NK, Jain KK, Ghughuskar MM, et al: Effects of dietary anthraquinone extract on growth, metabolic and haemato-immunological responses of Cirrhinus mrigala (Hamilton, 1822) fingerlings. Proceedings of the National Academy of Sciences: India Section B: Biological Sciences. India 2015 Springer India 2017 87(1): p 243-252.

11. Rao YV, Das BK, Pradhan J, Chakrabarti R: Effect of Achyranthes aspera on the immunity and survival of Labeo rohita infected with Aeromonas hydrophila. Fish Shellfish Immun. 2006 20: 263-273.

12. Citarasu T, Sivaram V, Immanuel G, Rout N, Murugan V: Influence of selected Indian immunostimulant herbs against white spot syndrome virus (WSSV) infection in black tiger shrimp, Penaeus monodon with reference to haematological, biochemical and immunological changes. Fish Shellfish Immunol. 2006 21: 372-384.

13. Cheng ZB, Ge CR, Han JZ: Effective constituents of Chinese herbal medicine on immune function of animals and its application. J Anim Sci Med. 2002 19:M1-M3 (in Chinese).

14. Xie J, Liu B, Zhou QL, Su YT, He YJ, Pan LK, et al: Effects of anthraquinones extract from rhubarb $R$. officinale Bail on the crowding stress response and growth of common carp (Cyprinus carpio var. Jian). Aquaculture. 2008 281: 5-18.

15. Liu B, Xianping G, Yanhui H, Xie J, Xu P, Yijin $\mathrm{H}$, et al: Effect of anthraquiones extracted from Rheum officinale bail on the growth, nonspecific immune response of Macrobrachium rosenbergii. Aquaculture. 2010 310:13-191.

16. Magnadottir B: Innate immunity of fish (overview). Fish Shellfish Immunol. 2006 20: 137-151

17. Ardo L, Yin G, Xu P, Varadi L, Szigeti G, Jeney $Z$ : Chinese herbs (Astragalus membranaceus and Lonicera japonica) and boron enhance the non-specific immune response of Nile tilapia (Oreochromis niloticus) and resistance against Aeromonas hydrophila. Aquaculture. 2008 275: 26-33

18. Anilakumar KR, Sudarshana-Krishna KR, Chandramohan G, Ilaiyaraja N, Khanum F, Bawa AS: Effect of Aloe vera gel some nonespecific immunity of red seabream Pagrus major. Fish Sci. 2010 73: 63-69

19. Labh SN, Shakya SR: Medicinal importance of Choerospondias axillaris (Roxb.) Burtt \& Hill fruits in Nepal. J Trop Plant Res. 2016 3(2): 463-469.

20. Shah DJ: Ascorbic acid (vitamin C) content of Lapsi- pulp and peel at different stage of maturation. Res Bull, 1978 (2035 BS, Food Research Section, HMGN, Department of 
Food and Agriculture Marketing Services, Kathmandu).

21. Li C, He J, Gao Y, Xing Y, Hou J, Tian J.: Preventive Effect of Total Flavones of Choerospondias axillaris on chemia/Reperfusion-Induced Myocardial Infarction-Related MAPK Signaling Pathway. Cardiovasc Toxicol. 2014 14: 145-152.

22. Zhou J, Huang J, Song XL: Applications of immunostimulants in aquaculture. Mar Fish Res. 2003 24:70-79.

23. Hosseini M, Jafarianheris T, Seddighi N, Parvaneh M, Ghorbani, A, Sadeghnia HR, et al: Effects of different extracts of Eugenia caryophyllata on pentylenetetrazoleinduced seizures in mice. Chin J Integr Med. 2012 10(12): 1476-81.

24. Gurung TB, Basnet SR: Introduction of rainbow trout (Oncorhynchus mykiss) in Nepal: Constraints and Prospects. Aquaculture Asia. 2003 3(4): 2003.

25. Ranzani-Paiva MJT, Rodrigues EL, Veiga ML, Eiras AC, Campos BES: Differential leukocytes counts in "dourado"Salminus maxillous" Valenciennes, 1840, from the Mogi- Guaçu River, Pirassiununga, SP. Bra J Biol. 2003 63: 517-525.

26. Tavares-Dias M, Schalch SEC, Moraes FR: Hematological characteristics of Brazilian teleosts. VII. Parameters of seven species collected in Guariba, São Paulo State, Brazil. Boletim do Instituo de Pesca. 2003 29: 109-115.

27. Cazenave J, Wunderlin DA, Hued AC, Bistoni MA: Haematological parameters in a neotropical fish, Corydoras paleatus (Jenys, 1842) (Pisces, Callichthydae), captured from pristine and polluted water. Hidrobiologia. 2005 537: 25-33.

28. Leonard JBK, McCormick SD. Changes in haematology during upstream migration migration in American shad. J Fish Biol. 1999 54 (1); 218-1230.

29. Zhiteneva LD. Naturally occuring ecological influence on ichthyo-haematology. Bull. Azov Sci. Res. Inst. of Fish Industry. 1999 1-53.

30. De Pedro N, Guijarro Ai, López-Patiño Ma, Martínez-Álvarez R, Delgado Mj: Daily and seasonal variations in hematological and biochemical parameters in the tench, Tinca tinca Linnaeus, 1758. Aquaculture Res. 2005 36(12): 1185-1196.

31. Ranzani-Paiva MJT, Godinho HM: Estudos hematologicos emcurimbata, Prochilodus scrofaSteindachner, 1881 (Osteichthyes, Cypriniformes, Prochilodontidae). SerieVermelha. Boletin do Instituto de pesca. 1985 12(2): 25-35.

32. Martins Ml, Pilarsky F, Onaka EM, Nomura DT, Fenerick JJ, Ribeiro K, et al: Haematology and acute inflammatory response of Oreochromis niloticus (Osteichthyes: Cichlidae) submitted to a single and consecutive stress of capture. Boletim do Instituto de Pesca. 2004 30(1); 71-80

33. Benli ACK, Yavuzcan HY: Blood parameters in Nile tilapia (Oreochromis niloticus L.) spontaneously infected with Edwardsiella tarda. Aquaculture Res. 2004 35(14); 13881390.

34. Martins ML, Mouriño JL, Amaral GV, Vieira FN, Dotta G, Jatobá AM, et al: Haematological changes in Nile tilapia experimentally infected with Enterococcus sp. Bra J Biol. 2008 68(3): 631-637.

35. Martins ML, Tavares-Dias M, Fujimoto RY, Onaka EM, Nomura DT: Haematological alterations of Leporinus macrocephalus (Osteichthyes: Anostomidae) naturally infected by Goezia leporine (Nematoda: Anisakidae) in fish pond. Arquivo Brasileiro de Medicina Veterinária e Zootecnia. 2004 56(5): 640-646

36. Thrall MA, Weiser G, Allison R, Campbell TW: Veterinary haematology and clinical chemistry. New Jersey, USA: WileyBlackwell. 2004 277-289.

37. Aderfemo OK: Haematological profile of Clarias gariepinus (Burchell, 1822) exposed to lead. Turkish. J Fish Aquat Sci. 2007 7: 163169.

38. Graham JB: Air-breathing Fishes: Evolution, diversity, and adaptation. Academic Press, San Diego. 1997.

39. Palanisamy SK, Ganakkan A, Senthil Kumar D, Jagadeesan L: Haematology and biochemical parameters of different feeding behaviour of teleost fishes from Vellar estuary, India. Comp Clin Pathol. 2011 21: 1187.

40. Rambhaskar B, Rao, KS: Comparative haematology of ten species of marine fish from Visakhapatnam Coast. J Fish Biol. 1986 30: 59-66.

41. Xiaoyun Z, Mingyun L, Khalid A, Weinmin $\mathrm{W}$ : Comparative of haematology and serum biochemistry of cultured and wild Dojo loach Misgurnus anguillicadatus. Fish Physiol Biochem. 2009 35: 435-441.

42. Arnold JE: Hematology of the sandbar shark, Carcharinus plumbeus: standardization of complete blood count techniques for elasmobranches. Vet Clin Pathol. 2005 34(2): 115-123.

43. Labh SN, Shakya SR, Kayasta BL: Extract of Medicinal lapsi Choerospondias axillaris (Roxb.) exhibit antioxidant activities during in vitro studies. J Pharmacogn Phytochem. 2015 4(3): 194-197.

44. Association of Official Analytical Chemists (AOAC). Official methods of analysis. 16th ed. Association of Official Analytical Chemists; Arlington, Virginia, USA. 1995. 
45. Dacie JV. Lewis SM: Practical haematology, 9th edition. Churchill Livingstone, London, 2001663.

46. Van Kampen EJ, Zijlstra NC: Determination of haemoglobin. Clin Chem Acta. 1961 5: 719720.

47. Britton CJ: Disorders of the Blood. 9th ed. I. A. Churchill, Ld.; London. 1963.

48. Shermer S: The blood morphology of laboratory animals. 3rd edition; F.A. Davis Company, Philadelphia, London. 1967 pp200

49. Hesser EF: Methods for routine fish haematology. Prog Fish Cult. 1960 22(4): 164171.

50. Wintrobe MM: Clinical haematology. Lea and Febiger, Philadelphia, 1967.

51. Levinson SA, Macfat RP: Clinical Laboratory Diagnosis. Lea and Febiger, Philadelphia. $1956: 1146$.

52. Blaxhall PC, Daisley KW: Routine haematological methods for use with fish blood. J fish biol. 1973 5: 771-781.

53. Rainza-Paiva MJT, Ishikawa CM, Das Eiras AA, Felizardo NN: Haematological analysis of 'chara' Pseudoplatystoma fasciatum in captivity. Aqua 2000. Responsible aquaculture in the new millennium. Nice, France May 2-6, 2000. European Aquaculture Soc. Special Pub. 2000 28: 590

54. Tewary A, Patra BC: Oral administration of baker's yeast (Saccharomyces cerevisiae) acts as a growth promoter and immunomodulator in Labeo rohita (Ham.). J Aquacult Res Dev. 2011 2: 109

55. Ezeri GNO. Haematological response of Clarias gariepinus to bacterial infection and prophylactic treatment with antibiotics, J Aquc Sci. 2001 16: 22-24.

56. Gabriel UU, Obomanu FG, Edori OS: Haematology, plasma enzymes and organ indices of Clarias gariepinus after intramuscular injection with aqueous leaves extracts of Lepidagathis alopecuroides. Afr J Biochem Res. 2009 3(9): 312-316.

57. Yasmin R, Pandey BN, Yasmin A: Seasonal variation in haematological indices with special reference to the effects of water temperature in Oreochromis mossambicus (Peters). J Freshw Biol. 1993 5(2): 177-181.

58. Iqbal MJ, Ali SS, Shakoon AR: Toxicity of lead in freshwater fish Cirrhinus mrigala Haematological changes. J Ecotoxicol Environ Monit. 1997 7(12): 139-143.

59. Harikrishnan R, Rani MN, Balasundaram C: Hematological and biochemical parameters in common carp, Cyprinus carpio, following herbal treatment for Aeromonas hydrophila infection. Aquaculture. 2003 221: 41-50.

60. Ologhobo AD: Nutritive values of some tropical (West African) legumes for poultry. J Appl Anim Res. 1992 2: 93-104.
61. Yılmaz S., Ergün S, Çelik EŞ: Effect of Dietary Spice Supplementations on Welfare Status of Sea Bass, Dicentrarchus labrax L. In: Proceedings of the National Academy of Sciences, India, Biological Sciences, 2014 Springer India 2016 86-299.

62. Marzouk MS, Moustafa MM, Mohamed NM: The Influence of some probiotics on the growth performance and intestinal microbial flora of Oreochromis niloticus. In: Proceedings of 8th International Symposium on Tilapia in Aquaculture. Cairo, Egypt, 2008 1059-1071.

63. Sahu S, Das BK, Pradhan J, Mohapatra BC, Mishra BK, Sarangi N: Effect of Magnifera indica kernel as a feed additive on immunity and resistance to Aeromonas hydrophila in Labeo rohita fingerlings. Fish Shellfish Immunol. 2007 23: 109-118.

64. Shalaby AM, Khattab YA, Abdel Rahman AM: Effects of (Allium sativum) and chloramphenicol on growth performance, physiological parameters and survival of Nile tilapia (Ooreochromis niloticus). J Venom Ani Toxins. 2006 12: 172-201

65. Faisal ASR: Adverse effects of some antimicrobial agents used in fish. Ph.D thesis, Faculty of Veterinary Medicine, Cairo University, Cairo. 2003.

66. Haghighi M, Sharif Rohani M: The effects of powdered ginger (Zingiber officinale) on the haematological and immunological parameters of rainbow trout Oncorhynchus mykiss. Asian J Marine Sci. 2013 1: 7-11.

67. Farahi A, Kasiri M, Sudagar M, Soleiman Iraei M, Zorriehzahra SMJ: Effect of dietary supplementation of Melissa Officinalis and Aloe Vera on haematological traits, lipid oxidation of carcass and performance in rainbow trout (Oncorhynchus Mykiss). Online J Animal Feed Res. 2012: 1: 1-5.

68. Sarma MD, Sapcto S, Sarma Gohain AK: Herbal growth promoters on hematobiochemical constituents in broilers. Indian Vet J. 2003 80: 946-948.

69. Manohar M: Probiotic and Spirulina as a Source of Immunostimulants and Growth in Common Carp. Ph.D. thesis, Manonmaniam Sundaranar University, Tamilnadu, India, 2005.

70. -Kumar R, Mukherjee SC, Prasad K, Pani Pal AK: Evaluation of Bacillus subtilis as a probiotic to Indian major carp, Labeo rohita. Aquaculture Res. 2006 37: 1215-12 